\section{Is the Fagerström Test for Nicotine Dependence a good instrument to assess tobacco use in patients with schizophrenia?}

0 Teste de Fagerström para Dependência de Nicotina é um bom instrumento para avaliar o uso de tabaco em pacientes com esquizofrenia?
Dear Editor,

We have read with great interest the article by Chaves and Shirakawa, ${ }^{1}$ in which the authors confirmed previous observations that patients with schizophrenia smoke in a higher rate as compared to the general population. They also observed that the patients were considered as heavy smokers according to the Fagerström Tolerance Questionnaire (FTQ).

Although the FTQ is considered to be adequate to assess nicotine dependence due to its extensive use, it suffers from significant psychometric shortcomings, such as low internal consistency and poor criterion validity. ${ }^{2}$ In order to address these problems, the Fagerström Test for Nicotine Dependence (FTND) was developed. The modifications of the FTQ consisted in the elimination of two items ("nicotine content of cigarette"; "frequency of inhalation") 
and in the expansion of the scoring format for two items ("time to first cigarette"; "number of cigarettes smoked per day"), resulting in a six-item questionnaire that provides a 0-10 score. The results from both the original study and subsequent research indicate that the FTND has satisfactory psychometric qualities due to its greater internal consistency and to the fact that it has a single factor. ${ }^{2}$ However, no studies to date have evaluated the psychometric properties of the translated Portuguese version of this instrument. We have recently ${ }^{3}$ examined this issue using the Brazilian version of the FTND in three different samples of smokers: university students $(n=61)$; patients of a Psychosocial Care Center for Alcohol and Drug Users (PCC-AD; $n=30$ ) and patients treated at an Emergency Unit and at the PCC-AD $(n=271)$. The FTND showed high reliability levels, with correlation coefficients of 0.92 for test-retest and 0.99 for inter-rater reliability. At the cut-off score of four, the instrument presented a sensitivity of 0.80 , specificity of 0.74 , positive predictive value of 0.95 , and negative predictive value of 0.30 . The evaluation of the internal consistency yielded a Cronbach's alpha coefficient of 0.83. An Exploratory Factorial Analysis found two factors in the FTND ('Smoking Pattern' and 'Morning Smoking' factors), attested by a Confirmatory Factor Analysis. Thus, the results obtained in our study confirm the efficiency of the Brazilian version of the FTND.

Nevertheless, few studies (none in the Brazilian context) have examined the psychometric properties of the FTND in smokers with schizophrenia. This would be particularly important since some questions have been raised about the applicability of the FTND to this population. The patients' smoking habits are usually controlled by others and there seem to exist differences between the smoking patterns, living arrangements, and daily routines of patients and healthy individuals. ${ }^{4}$ These factors are believed to produce an underestimation of nicotine dependence in schizophrenia, which may have a negative impact in the dosage of the nicotine replacement treatment if the FTND scores are used to guide it. ${ }^{4}$ For instance, Weinberger et al. studied the reliability of the FTND in smokers with schizophrenia and observed that the test-retest correlations were lower for patients than for controls $(0.65$ versus 0.82$) .{ }^{5}$ Moreover, when the test was administered to schizophrenia patients, lower internal consistency (Cronbach's alpha) and a non-conventional factorial structure were found. ${ }^{4}$ To date, as far as we know, there is no validity study of the FTND in patients with schizophrenia. ${ }^{2}$

Therefore, despite its wide use in research and clinical practice, the FTND still requires further psychometric investigation including patients with schizophrenia. In particular, studies evaluating its validity are necessary and opportune in order to provide the basis for the definition of specific cut-off points for this psychiatric population.

Carolina Menezes-Gaya

Mental Health Post-Gradutate Program, Faculdade de Medicina de Ribeirão Preto, Universidade de São Paulo (USP), Ribeirão Preto (SP), Brazil

Antonio Waldo Zuardi, Sonia Regina Loureiro, José Alexandre S. Crippa

Department of Behavioral Neurosciences, Faculdade de Medicina de Ribeirão Preto, Universidade de São Paulo (USP), Ribeirão Preto (SP), Brazil

Department of Behavioral Neurosciences, Faculdade de Medicina de Ribeirão Preto, Universidade de São Paulo (USP), Ribeirão Preto (SP), Brazil INCT Translacional Medicine (CNPq), Ribeirão Preto (SP), Brazil

\section{Disclosures}

\begin{tabular}{|c|c|c|c|c|c|c|c|}
\hline $\begin{array}{l}\text { Writting group } \\
\text { member }\end{array}$ & Employment & $\begin{array}{l}\text { Research } \\
\text { grant }^{1}\end{array}$ & $\begin{array}{c}\text { Other research grant } \\
\text { or medical continuous } \\
\text { education }\end{array}$ & $\begin{array}{l}\text { Speaker's } \\
\text { honoraria }\end{array}$ & $\begin{array}{c}\text { Ownership } \\
\text { interest }\end{array}$ & $\begin{array}{c}\text { Consultant/ } \\
\text { Advisory board }\end{array}$ & Other $^{3}$ \\
\hline $\begin{array}{l}\text { Carolina Menezes- } \\
\text { Gaya }\end{array}$ & FMRP-USP & FAPESP $^{\star *}$ & - & - & - & - & AstraZeneca* \\
\hline $\begin{array}{l}\text { Antonio Waldo } \\
\text { Zuardi }\end{array}$ & FMRP-USP & $\mathrm{CNPq}^{* *}$ & - & - & - & - & - \\
\hline $\begin{array}{l}\text { Sonia Regina } \\
\text { Loureiro }\end{array}$ & FMRP-USP & $\begin{array}{l}\text { FAPESP }^{* *} \\
\text { CNPq }^{* *}\end{array}$ & - & - & - & - & - \\
\hline $\begin{array}{l}\text { José Alexandre S. } \\
\text { Crippa }\end{array}$ & FMRP-USP & $\begin{array}{c}\text { FAPESP }^{* *} \\
\text { CNPq }^{* *} \\
\text { CAPES }^{* *} \\
\text { FAEPA* }^{*}\end{array}$ & FAEPA* & - & - & - & $\begin{array}{c}\text { FUNPEC* } \\
\text { Pfiser* } \\
\text { Elli-Lilly* } \\
\text { AstraZeneca* }\end{array}$ \\
\hline
\end{tabular}

* Modest

** Significant

*** Significant. Amounts given to the author's institution or to a colleague for research in which the author has participation, not directly to the author

Note: FMRP-USP = Faculdade de Medicina de Ribeirão Preto, Universidade de São Paulo; FAPESP = Fundação de Amparo à Pesquisa do Estado de São Paulo, $C N P q=$ Conselho Nacional de Desenvolvimento Científico e Tecnológico; CAPES = Coordenação de Aperfeiçoamento de Pessoal de Nivel Superior; FAEPA = Fundação de Apoio ao Ensino, Pesquisa e Assistência do Hospital das Clínicas da FMRP-USP; FUNPEC = Fundação de Pesquisas Cientificas.

For more information, see instructions for authors.

\section{References}

1. Chaves L, Shirakawa I. Nicotine use in patients with schizophrenia evaluated by the Fagerström Tolerance Questionnaire: a descriptive analysis from a Brazilian sample. Rev Bras Psiquiatr. 2008;30(4):350-2.

2. Meneses-Gaya IC, Zuardi AW, Loureiro SR, Crippa JA. Psychometric properties of the Fagerström Test for Nicotine Dependence. J Bras Pneumol. 2009;35(1):73-82.

3. Meneses-Gaya IC, Zuardi AW, Azevedo Marques JM, Souza RM, Loureiro SR, Crippa JA. Psychometric qualities of the Brazilian versions of the Fagerström Test for Nicotine Dependence (FTND) and of the Heaviness of Smoking Index (HSI). Nicotine Tob Res. In press 2009.

4. Steinberg ML, Williams JM, Steinberg HR, Krejci JA, Ziedonis DM. Applicability of the Fagerström Test for Nicotine Dependence in smokers with schizophrenia. Addict Behav. 2005;30(1):49-59.

5. Weinberger AH, Reutenauer EL, Allen TM, Termine A, Vessicchio JC, Sacco KA, Easton CJ, McKee SA, George TP. Reliability of the Fagerström Test for Nicotine Dependence, Minnesota Nicotine Withdrawal Scale, and Tiffany Questionnaire for Smoking Urges in smokers with and without schizophrenia. Drug Alcohol Depend. 2007;86(2-3):278-82. 